\title{
Analisis Penerapan Pasal tentang Tidak Melaporkan Adanya Tindak Pidana Narkotika Golongan 1 Bukan Tanaman
}

\author{
Wilda Aulia M.P, Lilik Puswastuty, Erwin \\ Fakultas Hukum, Universitas Jambi \\ Author's email correspondence: wildaaulia050998@gmail.com
}

\begin{abstract}
ABSTRAK
Artikel ini bertujuan untuk untuk mengetahui dan menganalisis dasar pertimbangan hukum dari Hakim dalam menjatuhkan Pasal 131 dalam Putusan Nomor 52/Pid.Sus/2019/Pn.Srl. Metode penelitian yang digunakan adalah metode yuridis normatif. Ada tiga dasar pertimbangan yaitu Pertimbangan fakta yuridis bahwa terdakwa terbukti bersalah melakukan tindak pidana tidak melaporkan adanya tindak pidana narkotika. Pelaku bukan hanya tidak melaporkan adanya tindak pidana, melainkan pelaku yang menyimpan shabu dan juga sebagai perantara pengantaran shabu. Hal yang memberatkan terdakwa yaitu terdakwa tidak mendukung program pemerintah, terdakwa tidak menyesali perbuatannya. Hal yang meringankan terdakwa yaitu terdakwa tidak berbelit-belit dalam memberikan keterangan, terdakwa mengaku terus terang, dan terdakwa belum pernah dihukum. Mengenai penerapan Pasal 131 Undang-Undang Nomor 35 Tahun 2009 tentang Nakotika di Pengadilan Negeri Sarolangun, sudah diterapkan di beberapa kasus yang diadili di Pengadilan Negeri Sarolangun, dan telah diterapkan dengan baik, namun terdapat beberapa kasus yang menurut penulis penerapan pasal pada perkara tersebut kurang tepat.
\end{abstract}

\section{ARTICLE HISTORY}

Submission: 2021-04-22

Accepted: 2021-04-25

Publish: 2021-04-26

KEYWORDS: criminal act; narcotics; report.
Kata Kunci: Melaporkan; narkotika; tindak pidana.

\section{ABSTRACT}

This article aims to find out and analyze the basis for legal considerations of the Judge Decision Number 52 / Pid.Sus / 2019 / $\mathrm{Pn}$. The research method used is a normative juridical. The results of the research show that the basis for the judge's consideration in imposing a sentence, the defendant was proven guilty. There are three basic considerations, namely consideration of juridical facts that the defendant is found guilty of committing a criminal act of not reporting the existence of a narcotics crime. The defendant was not the perpetrator who simply did not report a crime, but the perpetrator who kept methamphetamine and also acted as an intermediary for delivering methamphetamine as well. Whereas there were things that incriminated and lightened the defendant. The things that incriminated the defendant were that the defendant did not support the government program and what relieved the defendant, namely that the defendant was not convoluted in giving testimony, the defendant did not regret his actions, the defendant admitted frankly, and the defendant had never been convicted. Regarding the application of Article 131 of Law Number 35 of 2009 concerning Nakotika at the Sarolangun District Court, it has been applied in several cases that were tried at the Sarolangun District Court, and have been implemented properly, but there are several cases which according to the author the application of the article to the case is not right. 


\section{A. PENDAHULUAN}

Undang-Undang Nomor 35 Tahun 2009 tentang Narkotika Bab Xiii Pasal 104 sampai dengan Pasal 108 telah diatur tentang peran serta masyarakat, artinya masyarakat diberi wewenang untuk melaporkan adanya dugaan telah terjadi tindak pidana narkotika kepada penegak hukum atau Badan Narkotika Nasional (BNN). Hal ini merupakan salah satu bentuk wujud tanggungjawabnegara atas perlindungan terhadap warga negaranya adalah dengan memberi jaminan hukum dan tindakan nyata yang melindungi masyarakat dari segala bentuk kejahatan ${ }^{1}$.

Peran serta masyarakat yang terpayungi oleh hukum dalamUndang-Undang ini memberikan legitimasi bagi masyarakat untuk melakukan pencegahan dan pemberantasanTindak Pidana Narkotika yang sifatnya tidak diwajibkan.Sedangkan didalam Pasal 131 Undang-Undang Nomor 35 Tahun 2009 tentang Narkotikadiatur tentang kewajiban masyarakat melaporkantindak pidana narkotika.Maka perlu diketahuiapa yang dimaksud dengan masyarakat.Masyarakat merupakan manusia yang hidup bersama dalam ukuran sosial, bercampur dalam waktu yang cukup lama, dan merupakan suatu sistem yang setiap anggota kelompok merasa dirinya terikat satu dengan yang lain."Masyarakat adalah laksana organisme hidup"2.

Mengenai peran serta masyarakat untuk melaporkan adanya tindak pidana narkotika, di kabupaten Sarolangun dalam kurun waktu 3 tahun terakhir terdapat 2 kasus yang terungkap, yakni:

\begin{tabular}{llllll}
\hline NO & TAHUN & $\begin{array}{l}\text { NOMOR } \\
\text { PUTUSAN }\end{array}$ & DAKWAAN & PUTUSAN & $\begin{array}{l}\text { PASAL } \\
\text { YANG } \\
\text { TERBUKTI }\end{array}$ \\
\hline 1 & 2017 & $\begin{array}{l}\text { 27/Pid.Sus/2017 } \\
\text { /Pn.Srl }\end{array}$ & $\begin{array}{l}\text { Dikenakan } \\
\text { pasal 131 }\end{array}$ & 1 tahun & Pasal 131 \\
& & - & - & \\
\hline 2 & 2018 & - & Dakwaan & 1 tahun & 131 \\
\hline 3 & 2019 & $52 /$ Pid.Sus/2019 & Aternatif: & \\
& & /Pn.Srl & 1.pasal 114 & \\
& & & 2.pasal 112 & \\
& & & 3.pasal 131 & \\
\hline
\end{tabular}

Mengenai upaya penegakan hukum pemberantasan tindak pidana tidak melaporkan tindak pidana Narkotika, di Kabupaten Sarolangun terdapat kasus orang yang dengan sengaja tidak melaporkan adanya tindak pidana narkotika dalam kurun waktu 3 tahun terakhir yakni pada perkara nomor 52/Pid.Sus/2019/Pn.Srl dengan terdakwa atas nama Leni Marlina Binti Arifin yang didakwakan dengan 3 dakwaan yaitu Pasal 114 Ayat (2), Pasal 112 Ayat (2) dan Pasal 131 dan Pasal yang terbukti adalah Pasal 131.

Berawal pada bulan Agustus 2018 saudara Iwan menelepon terdakwa Leni Marlina binti Arifin untuk mengambil barang dan ketika terdakwa pergi menuju Pauh

1 Dheny Wahyudi, "Perlindungan Hukum Terhadap Korban Kejahatancyber Crime Di Indonesia", Jurnal Ilmu Hukum, hlm. 99. http://scholar.google.com/citations, diakses pada tanggal 22 desember 2019, jam 20:40.

2 Sultan dan Akilah Mahmud, "Konsep Masyarakat Menurut Murtadha Mathahhari”, Jurnal Sebuah Kajian Filsafat Social, Vol. Iv. No. 2 Tahun.2018, hlm. 270. http://www.google.com/search, diakses pada tanggal 22 desember 2019, jam 20:55. 
untuk bertemu dengan seseorang yang menanyakan apakah terdakwa Leni orang rumah,Iwan dan terdakwa menjawab "Iya", selanjutnya orang tersebut menyerahkan satu (1) kantong kain kepada terdakwa Leni Marlina Binti Arifin dan terdakwa membawa pulang kantong tersebut tanpa mengetahui isi didalam kantong tersebut dan menyimpannya di dalam lemari.

Pada Januari 2019 sekitar jam 08:00 saudara Iwan kembali menelepon terdakwa Leni untuk menanyakan barang yang lama itu masih ada atau tidak dan saudara Leni menjawab "Masih ada" setelah itu saudara Iwan mengatakan bahwa nanti ada orang kebun akan datang mengambil tetapi terdakwa Leni disuruh untuk tidak memberikannya di rumah, kemudian terdakwa mengambil kantong dan membukanya. Di dalam kantong terdapat 2 klip plastik dan terdakwa mengambil klip plstik yang lebih kecil dan membungkusnya kedalam tisu lalu memasukkan kedalam dompet yang akan dibawa ke Polongan Lubuk Kepayang.

Sesampainya disana, saksi Anwar sudah menunggu didekat sepeda motornya, kemudian terdakwa langsung menghampiri saksi Anwar dan membuka dompet kemudian memberikan satu klip plastik kepada saksi Anwar.Setelah menerima klip plastik yang berisikan narkotika jenis shabu, terdakwa mengatakan "Kalau tidak ada ini legak saksi" dan setelah itu terdakwa pulang kerumah terdakwa.

Bahwa sekitar pukul 13:30 wib, terdakwa sedang menuju Pauh, selanjutnya ditengah perjalanan datang saksi Fry Bob dan Saksi Harry menangkap dan membawa Terdakwa kedalam mobil yang didalamnya terdapat saksi Anwar. Dan saksi Fry Bob menanyakan apakah masih ada shabu disimpan lalu terdakwa mengatakan ada di rumah.Kemudian Terdakwa, saksi Anwar dibawa menuju rumah Terdakwa yang berada di Rt. 06 Desa Lubuk Kepayang Kec. Air Hitam Kab. Sarolangun, dan sesampainya dirumah Terdakwa tersebut, Saksi Fry Bob dan Saksi Hary melakukan penggeledahan terhadap rumah Terdakwa dengan disaksikan oleh Saksi H. Muhammad Yadi dan Saksi Sarmawi, kemudian Terdakwa mengambil 1(satu) kotak warna coklat merk Louis Vuiton, terdakwa buka kotak tersebut dan terdapat 1 (satu) klip plastik yang diduga berisikan Narkotika jenis shabu dan 1(satu) klip plastik yang berisikan 3 (tiga) klip plastik kosong, selanjutnya Terdakwa membawa Terdakwa dan barang bukti tersebut ke Polres Sarolangun.

Berdasarkan uraian unsur-unsur tersebut,Leni Marlina binti Arifin ini didakwakan dengan dakwaan alternative yakniPasal 114 Ayat (2), Pasal 112 Ayat (2) dan Pasal 131 dan Pasal yang diputus oleh hakim Adalah Pasal 131 Undang-Undang Nomor 35 Tahun 2009 tentang Narkotika.Berdasarkan kasus tersebut, apa yang menjadi dasar pertimbangan hukum hakim dalam menjatuhkan putusan. Dan bagaimana penerapan pasal. Karena yang penulis tangkap dari kronologi kasus tersebut terdakwa memenuhui semua unsur dalam 3 pasal yang didakwakan, tetapi mengapa Hakim menjatuhkan Pasal 131 Undang-Undang Nomor 35 tahun 2009 tentang Narkotia

\section{B. METODE PENELITIAN}

Penelitian ini menggunakan Penelitian Hukum, yang diperoleh dari studi perundang-undangan (statute approach), studi konsep (conceptual approach), studi kasus (case approach), dengan mempelajari perundang-undangan yang berkaitan 
dengan artikel ini, maka bisa dianalisa dari berbagai sudut pandang atas kasus yang di bahas ${ }^{3}$.

\section{PEMBAHASAN}

1. Dasar Pertimbangan Hukum Dari Hakim Dalam Menjatuhkan Pasal 131 Dalam Putusan Nomor 52/Pid.Sus/2019/Pn.Srl.

a. Pertimbangan Fakta Yuridis

Pertimbangan fakta yuridis adalah pertimbangan hukum yang menjadi dasar hakim dalam memutuskan suatu perkara pidana. Di dalam perkara Nomor 52/Pid.Sus/1019/Pn.Srl ini tindak pidana yang terbukti adalah tindak pidana tidak melaporkan adanya tindak pidana narkotika sebagaimana yang telah didakwakan terhadap terdakwa pada Pasal 131 Undang-Undang Nomor 35 Tahun 2009 tentang Narkotika, adapun unsur-unsur Pasal 131 sebagai berikut:

a. Unsur setiap orang yang dimaksud dengan setiap orang dalam pasal ini adalah menunjukkan tentang subyek/pelaku/siapa yang didakwakan melakukan tindak pidana dimaksud.Dan didalam perkara ini yang dimaksud dengan setiap orang adalah terdakwa yang bernama Leni Marlina binti Arifin.Terdakwa merupakan orang yang sehat jasmani dan rohani oleh karena itu terdakwa dapat bertanggungjawab secara hukum atas perbuatannya.

b. Unsur dengan sengaja tidak melaporkan kepemilikan narkotika golongan 1 (satu) dalam bentuk tanaman jenis shabu-shabu..

b. Pertimbangan fakta yang terungkap di persidangan

Fakta yang terungkap dipersidangan adalah suatu pertimbangan penting bagi hakim dan menjadi dasar bagi hakim untuk menjatuhkan suatu putusan dalm perkara pidana.Dan pertimbangan ini berdasarkan fakta-fakta yang terungkap selama di persidangan yaitu dilihat dari alat-alat bukti. Macam-macam alat-alat bukti terdapat pada Pasal 184 Ayat (1) Kitab Undang-Undang Hukum Acara Pidana (KUHAP) disebutkan bahwa alat bukti yang sah adalah: keterangan aksi, keterangan ahli, surat, petunjuk dan keterangan terdakwa.

Berdasarkan fakta yang terungkap dipersidanagn, berikut adalah alat bukti yakni keterangan saksi dan keterangan terdakwa sebagai berikut

a. Keterangan Saksi

1) Saksi Fry Bob Sihombing anak dari H. Sihombing

2) Saksi Harry Novrianto bin Samsul Hadi

3) Saksi Sarmawi Als Mawi bin Abdul Azis

4) Saksi Anwar bin Anang

b. Keteranagan Surat

Keterangan surat dalam hal ini berupa keterangan laboratoris nomor PM.01.05.881.01.19.136. Berdasarkan keterangan surat ini bahwa satu bungkus klip plastik yang disimpan dan diantara terdakwa kepada saksi Anwar termasuk narkotika golongan 1 berupa methamphetamine (bukan taman).

3 Moerti Hadiati Soeroso, Kekerasan dalam Rumah Tangga Dalam Perspektif Yuridis- Viktimologis, Sinar Grafika, Jakarta, 2011, hlm. 15. 


\section{c. Keterangan Terdakwa}

Terdakwa telah ditangkap pihak Kepolisian Sat Narkoba Polres Sarolangun, pada hari Selasa tanggal 08 Januari 2019 sekira pukul 13.30 Wib, di Jalan Pauh-Air Hitam tepatnya di Jembatan Pauh Jalan ke Air Hitam Kec. Pauh Kab. Sarolangun, setelah Terdakwa diamankan lalu dilakukan penggeledahan di rumah Terdakwa dan ditemukan 1 klip plastik berisikan serbukkristal narkotika jenis shabu.

c. Pertimbangan Sosiologis

Pertimbangan sosiologis adalah pertimbangan hakim yang bersifat non yuridis, artinya pertimbangan tidak diatur dalam suatu undang-undang.Hakim dalam menjatuhkan putusan Nomor 52/Pid.Sus/2019/Pn.Srl telah mempertimbangkan secara sosiologis bagi terdakwa.Dalam putusan tersebut diterangkan bahwa hakim tidak menemukan hal-hal yang dapat melepaskan terdakwa dari pertanggungjawaban pidana.Yakni hal-hal yang dapat menghilangkan sifat yang melawan hukum dari perbuatannya itu, baik secara alasan pembenar maupun sebagai alasan pemaaf.Hal tersebut berdasarkan ketentuan Pasal 193 Ayat (1) KUHAP terdakwa haruslah tetap dijatuhi pidana yang setimpal dengan kesalahannya.

Untuk membahas mengenai penerapan Pasal dalam Undang-Undang Narkotika, terlebih dahulu penulis mencoba menguraikan secara teoretis teori kausalitas tindak pidana. Teori kausalitas ini dimaksudkan untuk mencari:

1. Sebab akibat perbuatan pidana.

2. Menentukan pertanggungjawaban pelaku. ${ }^{4}$

Berdasarkan teori kausalitas tersebut, menurut penulis sebelum menerapkan suatu pasal terhadap pelaku tindak pidana, terlebih dahulu dilihat dari perbuatan terdakwa.Apa penyebab pelaku melakukan tindak pidana, dan bagaimana akibat dari perbuatan terdakwa.Sehingga barulah dapat ditentukan bentuk pertanggungjawaban pelaku.

Pasal 131 dalam Undang-Undang Narkotika tersebut, mengatur mengenai tindak pidana orang yang sengaja tidak melaporkan adanya tindak pidana narkotika.Salah satu terdakwa yang Diterapkan Pasal 131 Undang-Undang Nomr 35 Tahun 2009 tentang Narkotika yaitu terdakwa dalam putusan nomor 52/Pid.Sus/2019/Pn.Srl.

Terdakwa dalam perkara ini didakwakan oleh jaksa penuntut umum dengan dakwaan alternatif, yaitu Pasal 114 Ayat (2), atau Pasal 112 Ayat (2), atau Pasal 131. Dan oleh jaksa penuntut umum terdakwa terbukti memenuhi seluruh unsur Pasal 131 Undang-Undang Narkotika.

Mengacu kepada teori kausalitas yang telah penulis jelaskan sebelumnya, bahwa sebelum menerapkan suatu pasal, terlebih dahulu melihat sebab akibat dari tindak pidana yang dilakukan oleh pelaku dan barulah menentukan pertanggungjawaban.

Dalam perkara ini, penyebab terdakwa tidak melaporkan tindak pidana narkotika yaitu, terdakwa telah mengetahui bahwa barang yang telah terdakwa simpan

4 Bastianto Nugroho, Dkk, "Penerapan Pasal 112 Dan Pasal 127 Undang-Undang Nomor 35 Tahun 2009 Tentang Narkotika". Jurnal Media Hukum Dan Peradilan, Issn:2654-9178, http;//ww.google.com/search, HIm. 309. Diakses pada 5 juli 2020, jam. 20:00. 
selama 5 bulan di rumahnya tersebut adalah narkotika, kemudian pelaku mengantarkan narkotika jenis shabu tersebut kepada saksi (Anwar) dengan berat 9,82 gram.

Akibat dari perbuatan terdakwa tersebut, artinya terdakwa tidak mendukung program pemerintah dalam memberantas peredaran narkotika di Indonesia, yang mana Penyalahgunaan narkoba di Indonesia sudah sampai ke tingkat yang sangat mengkhawatirkan, fakta di lapangan menunjukkan bahwa $50 \%$ penghuni LAPAS (Lembaga Pemasyarakatan) disebabkan oleh kasus narkoba. ${ }^{5}$ Dan terdakwa harus dikenakan pasal yang sesuai dengan perbuatan pelaku. Terdakwa dalam perkara ini bukan hanya sebagai pelaku yang tidak melaporkan adanya tindak pidana narkotika, namun juga sebagai pelaku tindak pidana yang menyimpan sekaligus menjadi perantara memberi narkotika.

Dengan sebab akibat tersebut, bentuk pertanggungjawaban terdakwa seharusnya terdakwa putus denganPasal 112 Ayat (2) dan Pasal 114 Ayat (2) UndangUndang Narkotika.Karena terdakwa ini memang sebagai orang yang menyimpan narkotika, lalu juga sebagai orang yang menjadi perantara jual beli narkotika.Dan tidak tepat jika terdakwa hanya terbukti melakukan tindak pidana tidak melaporkan adanya tindak pidana narkotika, karena dia juga sebagai pelaku aktif dalam tindak pidana tersebut.Menimbang juga berat narkotika yang di simpan dan diantar oleh pelaku tidak sedikit yaitu melebihi 5 gram.

Berdasarkan pada kronologi kasus yang dipaparkan sebelumnya, terdakwa Leni Marlina diminta oleh saudara Iwan untuk mengambil narkotika pada seseorang, dan menyimpannya di lemari selama 5 bulan, setelah itu memberikan lagi narkotika itu kepada orang kebun yang disuruh oleh saudara Iwan. Berdasarkan hal tersebut terdakwa LeniMarlina telah memenuhi 3 unsur pasal yakni sebagai berikut:

Pasal 112 Undang-Undang Nomor 35 Tahun 2009 tentang Narkotika, sebagai berikut:

1. Unsur setiap orang Yang dimaksud dengan setiap orang dalam pasal ini adalah menujukkan tentang subyek/pelaku/siapa yang didakwakan melakukan tindak pidana yakni terdakwa yang bernama Leni Marlina binti Arifin

2. Unsur tanpa hak atau melawan hukum memiliki, menyimpan, menguasai atau menyediakan narkotika golongan 1 dalam bentuk bukan tanaman.Yang dimaksud dengan tanpa hak yaitu sipelakuLeni Marlina dalam melakukan perbuatannya tidak memiliki hak sama sekali untuk melakukan perbuatan yang dilakukan yakni menyimpan narkotika. Sedangkanyang dimaksud dengan melawan hukum yaitu perbuatan sipelaku telah melanggar/menyimpang dari ketentuan perundang-undangan.Yang dimaksud dengan narkotika berdasarkan pengertian yang diberikan oleh Pasal 1 undang-undang nomor 35 tahun 2009 tentang narkotika.Dan unsur ini bersifat alternatif, oleh karenanya apabila salah satu hal yang berada dalam unsur ini telah terpenuhi, maka sudah cukup untuk menyatakan unsur ini telah terpenuhi oleh perbuatan terdakwa.Menimbang bahwa berdasarkan uraian fakta hukum dipersidangan,

5 Fransiska Novita Eleanora, "Bahaya Penyalahgunaan Narkoba Serta Usaha Pencegahan Dan Penanggulangan (Suatu Tinjauan Teoritis)", Jurnal Hukum, Vol. Xxv, No. 1, Tahun 2011, Http://Www.Google.Com/Search, hlm. 440. 
maka Hakim anggota 1 berpendapat unsur "menyimpan dan menyediakan narkotika golongan 1 dalam bentuk bukan tanaman" telah terpenuhi.

3. Unsur yang beratnya melebihi 5 (lima) gram Bahwa setelah dilakukannya penimbangan terhadap barang bukti narkotika yang diserahkan oleh terdakwa Leni Marlina kepada saksi Anwar (terdakwa dalam berkas terpisah) dan barang bukti yang disimpan terdakwa dalam lemari pakaiannya melebihi 5 gram berdasarkan berita acara penimbangan dan penyisihan barang bukti.Menimbang berdasarkan uraian tersebut maka Hakim anggota 1 berpendapat unsur "yang beratnya melebihi 5 (lima) gram" terpenuhi.

Dalam Pasal 114 Undang-Undang Nomor 35 Tahun 2009 tentang Narkotika, sebagai berikut:

1. Unsur setiap orang yang dimaksud dengan setiap orang dalam pasal ini adalah menujukkan tentang subyek/pelaku/siapa yang didakwakan melakukan tindak pidana yang dimaksud didalam perkara ini adalah terdakwa yang bernama Leni Marlina binti Arifin.

2. Unsur tanpa hak melawan hukum menawarkan untuk dijual, menjual, membeli, menerima, menjadi operantara dalam jual beli , menukar, atau menyerahkan narkotika golongan 1 . Yang dimaksud dengan tanpa hak yaitu sipelaku dalam melakukan perbuatannya tidak memiliki hak sama sekali untuk melakukan perbuatan yang dilakukan, sedangkan yang dimaksud dengan melawan hukum yaitu perbuatan sipelaku telah melanggar/menyimpang dari ketentuan perundang-undangan. Menimbang bawaberdasarkan fakta dipersidangan terdakwa Leni Marlina di telepon oleh saudara Iwan untuk mengambil barang (yang diduga narkotika) dan setelah itu terdakwa Leni Marlina simpan dilemarinya selama 5 bulan dan setelah itu terdakwa Leni Marlina di telepon kembali oleh saudara Iwan, bahwa akan ada orang yang mengambil barang tersebut dan memberikan barang tersebut kepada orang kebun yang dimaksud saudara Iwan. Berdasarkan fakta tersebut menurut penulis unsur "menjadi perantara dalam jual beli" terpenuhi.

3. Unsur yang beratnya melebihi 5 gram. Bahwa setelah dilakukannya penimbangan terhadap barang bukti narkotika yang diserahkan oleh terdakwa Leni Marlina kepada saksi Anwar (terdakwa dalam berkas terpisah) dan barang bukti yang disimpan terdakwa dalam lemari pakaiannya berdasarkan berita acara penimbangan dan penyisihan barang bukti bahwa narkotika tersebut seberat 9,82 (sembilan koma delapan puluh dua) gram. Menimbang berdasarkan uraian tersebut maka Hakim anggota 1 berpendapat unsur "yang beratnya melebihi 5 (lima) gram" terpenuhi.

Bahwa penulis telah melakukan wawancara terhadap salah satu hakim yang memutus perkara nomor 52/Pid.Sus/2019/Pn.Srl ini, yang kesimpulannya sebagai berikut:

1. Seharunya dakwaan pada putusan nomor 52/Pid.Sus/2019/Pn.Srl seharusnya bersifat komulatif bukan alternatif.

2. Seharusnya jaksa penuntut umum tidak menuntut terdakwa dengan Pasal 131 Undang-Undang Nomor 35 Tahun 2009 tentang Narkotila, karena berdasarkan keterangan saksi-saksi, alat bukti dan fakta-fakta dipersidangan. Terdakwa 
terbukti melakukan tindak pidana menyimpan dan menjadi perantara memberi narkotika melebihi lima gram yang sebagaimana dimaksud didalam Pasal 112 ayat (2)

Berdasarkan fakta-fakta dipersidangan terdakwa Leni Marlina tidak patut menjadi orang yang hanya tidak mengetahui saja adanya tindak pidana narkotika, karena barang tersebut berasal dari terdakwa dan terdakwa menyimpan barang tersebut selama 5 bulan.

Berdasarkan hasil wawancara tersebut, dan fakta-fakta dipersidangan.Penerapan pasal 131 undang-undang nomor 35 tahun 2009 tentang narkotika tidak tepat. Dikarenakan salahnya jaksa penuntut umum dalam menyusun dakwaan terhadap terdakwa, serta jaksa keliru dalam menuntut terdakwa dengan Pasal 131 undang-undang nomor 35 tahun 2009 tentang narkotika.

Jaksa dalam perkara ini menyusu dakwaan secara alternatif.Dakwaan alternatif itu sendiri merupakan bentuk dakwaan yang digunakan jika belum didapat tindak pidana mana yang pantas dibuktikan.Dakwaan alternatif ini terdiri dari beberapa lapisan, dan hanya satu dakwaan yang dibuktikan tanpa harus memperhatikan urutannya. Menurut penulis dan bapak hakim anggota satu berpendapat bahwa Seharusnya jaksa penuntut umum menyusun dakwaan secara komulatif terhadap perkara ini.

Penulis telah melakukan wawancara juga terhadap salah satu jaksa penuntut umum yang membuat dakwaan pada perkara Nomor 52/Pid.Sus/2019/Pn.Srl ini, yang kesimpulannya sebagai berikut:

1. Hal-hal yang harus diperhatikan dalam membuat surat dakwaan terhadap pelaku tindak pidana adalah harus melalui syarat-syarat formil dan materil (Pasal 143 KUHAP) yakni dicantumkannya tanggal, tanda tangan penuntut umum, dan identitas lengkap terdakwa. Serta urain secara cermat, jelas dan lengkap mengenai tindak pidana yang didakwaakan dengan menyebut waktu dan tempat tindak pidana itu dilakukan.

2. Terdakwa dalam perkara Nomor 52/Pid.Sus/2019/Pn.Srl didakwakan dengan dakwaan alternatif karena di bab 15 pasal yang sama, penuntut umum wajib disertai dengan Surat Dakwaan Jaksa Agung Nomor Se-004/J.A/11/1993 tentang format dakwaan dan dalam hal tersebut dijelaskan terkait dakwaan. Dan pada perkara Nomor 52/Pid.Sus/2019/Pn.Srl terdakwa atas namaLeni Marlina binti Arifinterdakwa melakukan satu tindak pidana dalam UndangUndang narkotika dan belum dapat dijelaskan tentang klasifikasi dan ketentuan pidana yang dilanggar, maka dipergunakan dakwaan alternatif.

3. Dasar pertimbangan jaksa penuntut umum dalam perkara Nomor 52/Pid.Sus/2019/Pn.Srl, jaksa penuntut umum menuntut terdakwa dengan Pasal 131 bukan Pasal 114 Ayat (2) ataupun Pasal 112 Ayat (2) Undang-Undang Nomor 35 Tahun 2019 tentang Narkotika adalah sebagai berikut:
a. Sebagai perantara: Berdasarkan keterangan terdakwa dan bukti-bukti dipersidangan kurang terbukti (tipis)
b. Sebagai penyimpan: Kurang terbukti, tipis (karena terdakwa tidak tau kalo barang yg disimpan adalah narkotika) (tipis)
c. Tidak melaporkan: terbukti karena dia mengakuinya. 
Berdasarkan hal tersebut jaksa penuntut umum menuntut terdakwa dengan Pasal 131 yang menurut jaksa penuntut umum, pasal tersebut yang pasti dan terdakwa mengakuinya.

Berdasarkan penelitian yang telah penulis lakukan, penulis berkesimpulan bahwa dasar pertimbangan hakim pada putusan Nomor 52/Pid.Sus/2019/Pn.Srl, sebagai berikut:

1. Pertimbangan Fakta Yuridis

Putusan ini terdakwa terbukti melakukan tindak pidana tidak melaporkan adanya tindak pidana narkotika sebagaimana dakwaan jaksa penuntut umum yaitu dakwaan alternative yang ketiga Pasal 131 Undang-Undang Nomor 35 Tahun 2009 TentangNarkotika mengenai Tindak Pidana Tidak Melaporkan Adanya Tindak Pidana Narkotika. Dan pasal ini telah terbukti maka dakwaan selanjutnya tidak perlu dibuktikan lagi.

Unsur-unsur Pasal dalam Pasal 131 Undang-Undang Nomor 35 Tahun 2019 tentang Narkotika telah terpenuhi terhadap diri terdakwa, makadari itu hakim menjatuhkan putusan 1 tahun penjara terhaadap terdakwa. Namun menurut penulis Pasal 131 Undang-Undang Nomor 35 Tahun 2009 tentang Narkotika ini tidaklah tepat. Karena secara yuridis terdakwa ini lebih memenuhi unsur Pasal 112 Ayat (2) dan Pasal 114 Ayat (2) Undang-Undang Nomor 35 Tahun 2009 tentang Narkotika.Karena terdakwa menyimpan barang yang diduga narkotika selam 5 bulan dan setelah itu menjadi perantara menyerahkan barang yang diduga narkotika kepada saudara saksi maka dengan putusan hakim yang hanya satu tahun itu sangatlah tidak tepat.

2. Fakta-Fakta di Persidangan.

Berdasarkan fakta-fakta yang terungkap di persidangan ini mulai dari barang bukti, keterangan saksi-saksi, keterangan surat dan keterangan terdakwa sendiri terdakwa dijatuhkan putusan satu tahun penjara oleh majelis hakim karena tebukti melakukan tindak pidana tidak melaporkan adanya tindak pidana narkotika.

Namun menurut penulis putusan yang diputuskan oleh hakim tidak tepat karena berdasarkan kronologi pada putusan nomor 52/Pid.Sus/2019/Pn.Srl. Berawal pada bulan Agustus 2018 terdakwa ditelepon oleh sdr.Iwan untuk mengambil barang dari seseorang tersebut dan menyimpan barang tersebut dilemarinya selama 5 bulan dan setelah penimbangan berita acara bahwa barang tersebut beratnya melebihi 5 gram..

3. Pertimbangan fakta sosiologis

Fakta sosiologis merupakan fakta yang wajib dimuat oleh hakim dalam suatu putusan, yakni sebagai berikut:

a. Fakta yang memberatkan

Keaadan yang memberatkan pidana ada 2 yaitu legal aggravating circumstancesdan judicial aggravating circumstances. ${ }^{6}$. Dalam putusan ini hal yang memberaratkan pada diri terdakwa sebagai berikut:

Dwi Hanata, "Pertimbangan Keadaan-Keadaan Meringankan Dan Memberatkan Dalam Penjatuhan Pidana", Jurnal Aggravating And Mitigating Circumstances Consideration On Sentence. Vol. 7, No.1, Tahun 2018, hlm.92.http:www.Jurnal hokum dan peradilan.Org/ Index.Php/Jurnal hukumperadilan/Article/Download/185/15.Diakses pada 29 juli 2020, jam 21:00. 
Perbuatan terdakwa tidak sejalan dengan program pemerintah yang saat ini tengah giat-giatnya memberantas segala bentuk penyalahgunaan narkotika dan obat-obat terlarang lainnya.Hal tersebut sejalan dengan tujuan dibentuknya Undang-Undang Nomor 35 Tahun 2009 Tentang Narkotika, bahwa Undang-Undang ini dibentuk karena tindak pidana narkotika ini sangat merugikan merupakan bahaya sangat besar bagi kehidupan masyarakat, bangsa dan Negara serta ketahanan nasional Indonesia.

b. Fakta yang meringankan

Keadaan yang meringankan yang termasuk Judicialmitigating circumstances dapat dilihat dalam hukum pidana Romania, sebagai berikut:

1) Upaya pelaku untuk menghilangkan atau mengurangi tingkat keseriusan dari tindak pidana

2) Keadaan-keadaan yang berkaitan dengan tindak pidana yang dilakukan, yang mengurangi tingkat keseriusan dari tindak pidananya atau ancaman bahaya dari pelakunya ${ }^{7}$.

Keadaan yang meringankan dalam putusan ini sebagai berikut:

- Terdakwa tidak berbelit-belit dalam memberikan keterangan, berarti terdakwa kooperatif dalam mendukung proses hukum, sehingga membantu proses kelancaran sehingga efisiensi dalam menggunakan waktu.

- Terdakwa menyesali perbuatannya. Hal ini sesuai dengan tujuan pemidanaan Indonesia yaitu menggunakan teori gabungan, bahwa pidana bukan hanya suatu pembalasan melainkan ada tujuan yang ingin dicapai.

- Terdakwa mengaku terus terang. Selama pernyataan yang diajukan didalam persidangan terdakwa menjawab secara terus terang dan tidak berbelit, maka hal tersebut dapat dijadikan hakim sebagai alsan untuk meringankan sanksi pidana yang akan dijatuhkan8.

- Terdakwa belum pernah dihukum. Terdakwa belum pernah dihukum karena melakukan tindak pidana sebelumya, hal ini menjadi catatan pertimbangan tersendiri bagi hakim untuk menjatuhkan putusan terhadap terdakwa sebagai dasar yang meringankan sanksi pidana ${ }^{9}$.

Berdasarkan uraian diatas, penulis berkesimpulan bahwa terdakwa bukan sebagai pelaku tindak pidana tidak melaporkan adanya tindak pidana narkotika, melainkan pelaku tindak pidanna menyimpan narkotika sebagaimana diatur dalam Pasal 112 Undang-Undang Nomor 35 Tahun 2009 tentang Narkotika dan tindak pidana menjadi perantara dalam jual beli narkotika sabagaimana diatur dalam Pasal 114 Undang-Undang Nomor 35 Tahun 2009 tentang Narkotika.

Ibid. hlm. 97.

8 Suci Kurnia Ramadhani, “Dasar Pertimbangan Hakim Dalam Menjatuhkan Sanksi Pidana Penjara Terhadap Pelaku Tindak Pidana Pencurian Dengan Kekerasan (Studi Pengadilan Negeri Siduarjo", Jurnal Fakultas Hukum Brawijaya, hlm. 4, Http://Www.Google.Chrome.Com, Diakses Pada 1 September 2020, Jam 10:00. Ibid. 
Dan menurut penulis hakim keliru telah memutuskan terdakwa terbukti atas Pasal 131 Undang-Undang narkotika, karena berdasarkan ketentuan Pasal 182 Ayat (4) KUHAP maka hakim bermusyawarah dalam membuat suatu putusan, dengan memperhatikan 2 hal sebagai berikut:

1. Surat dakwaan dari jaksa penuntut umum

2. Segala yang terbukti dalam pemeriksaan di persidangan (apabila ada sekurangkurangnya dua alat bukti yang sah yang meyakinkan hakim atas suatu tindak pidana dan pelaku tindak pidana tersebut, pasal 183 KUHAP. ${ }^{10}$

Dari penjabaran di atas, menurut penulis hakim dalam perkara ini tetap bisa menerapkan Pasal 112 Ayat (2) Undang-Undang Nomor 3 Tahun 2009 tentang Narkotika terhadap terdakwa walaupun dakwaan bersifat alternatif dan yang dituntut oleh jaksa penuntut umum adalah Pasal 131 Undang-Undang Narkotika saja.Karena Hakim mempunyai kebebasan mandiri dalam mempertimbangkan berat ringannya sanksi pidana penjara terhadap putusan yang ditanganinya. Kebebasan hakim mutlak dan tidak dicampuri oleh pihak lain. ${ }^{11}$ Karena hakim memutuskan perkara harus berdasarkan surat dakwaan, dan terdakwa dalam perkara ini telah didakwaakan dengan Pasal 112 ayat (2) undang-undang narkotika, namun hakim malah telah menjatuhkan terdakwa terbukti atas pasal 131 undang-undang narkotika.

Setiap masyarakat tidak dapat menghindari terjadinya suatu konflik, baik itu konflik antar pribadi, antar dan kelompok, antar kelompok, dan antara pribadi, kelompok dengan Negara.Oleh karena itu dalam sistem hukum dari suatu Negara, dalamnya mencakup pula pengaturan mekanisme penyelesaian sengketa.Di Indonesia penyelesaian perkara pidana dilakukan berdasarkan hukum acara pidana sebagaimana diatur dalam Undang-Undang Nomor 8 Tahun 1981 Tentang Hukum Acara Pidana (KUHAP). 12

Dan menurut penulis, dengan dijatuhkannya Pasal 131 Undang-Undang Narkotika terhadap terdakwa, dan bukan Pasal 112 Ayat (2) menjadikan putusan ini tidak sesuai dengan tujuan pemidanaan, yakni dimana salah-satu tujuan pemidanaan ini agar pelaku jera dan tidak mengulangi perbuatan tersebut. Jika dilihat pula melaui teori-teori keadilan, bahwa berdasarkan keadilan retrbutif bahwa orientasi keadilan itu mengacu kepada si pelanggar dan menjatuhkan pidana sebagai rasionalisasi dari pembalasan atas pelanggaran hukum pidana. Sedangkan berdasarkan teori Restoratif bahwa orientasi keadilan itu mengacu kepada kepentingan korban dan pemidanaan dijatuhkan sebagai pertanggungjawaban pelanggar terhadap akibat perbuatannya ${ }^{13}$.

Menurut teori keadilan korektif, bahwa jika suatu kejahatan telah dilakukan maka hukuman yang sepantasnya perlu diberikan kepada si pelaku. Bagaimanapun ketidakadilan akan mengakibatkan terganggunya kesetaraan yang sudah mapan atau telah terbentuk. Keadilan korektif bertugas membangun kembali kesetaraan tersebut ${ }^{14}$. Jeremi Bebtham dan sebagian besar penulis modern yang lain selalu menyatakan

${ }^{10}$ http://www.hukumonline.com/klinik/detail/ulasan/c14315, diakses pada 09 jully 2020, pada jam 20:00.

11 Suci Kurnia Ramadhani, Op.Cit, hlm. 4.

12 Usman, Andi Najemi, Mediasi Penal di Indonesia: Keadilan, Kemanfaatan, dan Kepastian Hukumnya, Undang-undang: Jurnal Hukum, Vol. 1, No. 1, 2018. https://ujh.unja.ac.id/ index.php/ home/article/view/17/4, Diakses pada tanggal 03 maret 2020.

13 Usman dan Andi Najemi, Op.Cit, hlm 77

14 Ibid. 
bahwa tujuan pemidanaan adalah untuk mencegah dilakukannya kejahatan pada masa yang akan datang. ${ }^{15}$

Dari teori-teori keadilan yang dipaparkan di atas, maka menurut penulis penerapan Pasal 131 terhadap terdakwa dalam perkara ini tidaklah mencerminkan nilai-nilai keadilan. Karena berdasarkan teori keadilan yang ada, bahwa seharusnya agar tercapai suatu keadilan maka teorinya harus menimpakan suatu pidana sesuai apa yang telah dilanggar oleh si pelanggar sebagai akibat dari perbuatan yang telah dilakukan.

\section{SIMPULAN}

Dasar pertimbangan hukum hakim dalam menjatuhkan putusan terdakwa terbukti melakukan tindak pidana tidak melaporkan adanya tindak pidana narkotika, tindak pidana menyimpan narkotika dan tindak pidana menjadi perantara dalam jual beli narkotika. Tetapi yang diputuskan hanya Pasal 131 Undang-Undang Nomor 35 Tahun 2009 tentang Narkotika, dikarenakan dakwaan yang bersifat alternatif. Maka hakim memutuskan berdasarkan tuntutan dakwaan.

\section{DAFTAR PUSTAKA}

\section{Dokumen Hukum}

Republik Indonesia. Undang-Undang Tentang Narkotika. Undang-Undang Nomor 35 Tahun 2009. Lembaran Negara Republik Indonesia Tahun 2009 Nomor 143. Tambahan Lembaran Negara Republik Indonesia 5059

Republik Indonesia. Kitab Undang-Undang Hukum Pidana.

Republik Indonesia. Kitab Undang-Undang Hukum Acara Pidana

Republik Indonesia. Undang-Undang Tentang Perubahan atas Undang-Undang Nomor 31 Tahun 1999 Tentang Pemberantasan Tindak Pidana Korupsi. UU Nomor 20 Tahun 2001. LNRI Tahun 2001 Nomor 134, TLNRI Nomor 4150.

\section{Buku:}

Priyatno, Dwidja. Sistem Pelaksanaan Pidana Penjara di Indonesia, Cet.3, Pt. Refika Aditama, Bandung, 2013.

Soeroso, Moerti Hadiati. Kekerasan dalam Rumah Tangga dalam Perspektif YuridisViktimologis, Sinar Grafika, Jakarta, 2011.

\section{Jurnal}

Eleanora, Fransiska Novita. "Bahaya Penyalahgunaan Narkoba Serta Usaha Pencegahan Dan Penanggulangannya (Suatu Tinjauan Teoritis)",Jurnal Hukum, Vol. Xxv, No. 1, 2011. http://scholar.google.com/citations.

15 Dwidja Prianto, System Pelaksanaan Pidana Penjara di Indonesia, Cet 3, Pt.Refika Aditama, Bandung, 2013, hlm. 23. 
Hanata, Dwi. "Pertimbangan Keadaan-Keadaan Meringankan Dan Memberatkan Dalam Penjatuhan Pidana", Jurnal Aggravating And Mitigating Circumstances Consideration On Sentence. Vol. 7, No.1, 2018

http:www.Jurnalhukumdanperadilan.Org/Index.Php/,/Jurnalhukumperadilan/A rticle/Download/185/165.

Nugroho, Bastianto, Dkk. "Penerapan Pasal 112 Dan Pasal 127 Undang-Undang Nomor 35 Tahun 2009 Tentang Narkotika". Jurnal Media Hukum Dan Peradilan, Issn:2654-9178. http;//ww.google.com.

Ramadani, Suci Kurnia.“Dasar Pertimbangan Hakim Dalam Menjatuhkan Sanksi Pidana Penjara Terhadap Pelaku Tindak Pidana Pencurian Dengan Kekerasan”.Skripsi. Fakultas Hukum Univesitas Brawijaya.2013.

http:www.Jurnalhukumdanperadilan.Org/Index.Php/,/Jurnalhukumperadilan/A rticle/Download/185/165.

Sultan dan Mahmud, Akilah. "Konsep Masyarakat Menurut Murtadha Muthahhari(Sebuah Kajian Filsafat Sosial)". Jurnal Aqidah-Ta. Vol. IV. No. 2. 2018. http://www.google.com/search.

Usman,. Najemi, Andi. Mediasi Penal di Indonesia: Keadilan, Kemanfaatan, dan Kepastian Hukumnya, Undang-undang: Jurnal Hukum, Vol. 1, No. 1, 2018. https://ujh.unja.ac.id/index.php/home/article/view/17/4,

Wahyudi, Dheny "Perlindungan Hukum Terhadap Korban Kejahatan Cyber Crime Di Indonesia". Jurnal Ilmu Hukum. 